Cakrawala Dini: Jurnal Pendidikan Anak Usia Dini | p-ISSN 2087-I317 | e-ISSN 262I-8321

Vol. 10. No.2 November 2019 | Hal I5I-155

\title{
PERANCANGAN DAN IMPLEMENTASI APLIKASI PERMAINAN EDUKATIF BAGI SISWA PAUD
}

\author{
Olivia Kembuan ${ }^{1}$, Ni Dewi Eka Suwaryaningrat ${ }^{2}$, Merry Cristin Natalia Liow ${ }^{3}$ \\ ${ }^{1,2,3}$ Universitas Negeri Manado
}

\begin{abstract}
One of the principle in pre-school education is play-based learning. This research utilizes technology to develop computer games based media learning for preschoolers. We used Multimedia Development Life Cycle (MDLC) to develop this application. There are six stages in this sistem development method; these six steps include concept, design, material collecting, assembly, testing, and distribution. These media have five features using Indonesian language, -namely, riddles games, simple counting games, drawing menu, words construct game and coloring menu. This media learning game was implemented to fifteen preschool students with an age range between 3-5 years with their teacher accompaniment. The result showed that this application could be used as an alternative media learning for the student and the teacher of preschool to develop the children creativity and competencies.
\end{abstract}

Keyword: educational game, pre-schoolers

\begin{abstract}
Abstrak: Salah satu prinsip pelaksanaan Pendidikan Anak Usia Dini (PAUD) yaitu belajar melalui bermain atau bermain seraya belajar. Penelitian ini memanfaatkan teknologi untuk mengembangkan media pembelajaran anak berbasis aplikasi permainan. Metode pengembangan sistem yang digunakan dalam kegiatan ini adalah metodologi Multimedia Development Life Cycle (MDLC) yang terdiri dari enam tahap, yaitu perumusan konsep (concept), perancangan (design), pengumpulan materi (material collecting), pembuatan (assembly), pengujian (testing), dan pendistribusian (distribution). Aplikasi permainan edukatif berbahasa Indonesia ini memiliki 5 (lima) fitur yang dapat dimainkan secara acak antara lain, Menu Tebak-tebakkan, Menu Berhitung, Menu Menggambar, Menu Susun kata, dan Menu Mewarnai. Aplikasi ini diuji-coba pada 15 (lima belas) orang siswa PAUD berusia 3-5 Tahun dengan bimbingan para tenaga pendidik. Aplikasi permainan ini dapat digunakan sebagai media pembelajaran alternatif pembelajaran guru dan siswa Pendidikan Anak Usia Dini (PAUD) dalam mengembangkan kreativitas dan kompetensi anak.
\end{abstract}

Kata Kunci: Permainan edukatif, PAUD

\footnotetext{
' Universitas Negeri Manada, Email: aliviakembuan国unima.ac.id

${ }^{2}$ Universitas Negeri Manada, Email: nidewiekha回unima.ac.id

${ }^{3}$ Universitas Negeri Manada, Email: liowmerгy国gmail.com
} 


\section{PENDAHULUAN}

Pendidikan untuk anak usia dini memegang peranan sangat penting pada pembentukan generasi penerus bangsa Indonesia di masa depan. Kebanyakan anak-anak Indonesia dalam memulai proses masuk ke lembaga pendidikan, mengabaikan pendidikan anak usia dini, padahal untuk membisaakan diri dan mengembangkan pola pikir anak, pendidikan sejak usia dini mutlak diperlukan.

Montessori (dalam Hainstock, 1999, hlm.12) menyatakan bahwa pada rentang usia lahir sampai 6 (enam) tahun anak mengalami masa keemasan (the golden years) yang merupakan masa di mana anak mulai peka/sensitif untuk menerima berbagai rangsangan. Masa peka adalah masa terjadinya kematangan fungsi fisik dan psikis, anak telah siap merespon stimulasi yang diberikan oleh lingkungan. Menurut hasil penelitian Osborn, White dan Bloom dalam Ernawati (2009), pada usia 4 (empat) tahun pertama separuh kecerdasan manusia sudah terbentuk. Artinya jika pada usia tersebut otak anak tidak mendapat rangsangan secara maksimal, maka potensi anak tidak akan berkembang secara optimal.

Dalam melaksanakan Pendidikan Anak Usia Dini (PAUD) terdapat prinsipprinsip utama yang harus diperhatikan. Salah satu prinsipnya yaitu belajar melalui bermain atau bermain seraya belajar. Bermain merupakan suatu kegiatan yang dilakukan dengan atau tanpa alat yang menghasilkan pengertian atau memberikan informasi, memberikan kesenangan maupun mengembangkan imajinasi pada anak (Sudono, 2000). Sedangkan belajar merupakan aktivitas mental atau psikis yang berlangsung dalam interaksi aktif dengan lingkungan yang menghasilkan perubahan dalam pengetahuan, pemahaman, keterampilan, dan nilai sikap (Darsono, 2000).

Saat ini, pembelajaran berbasis teknologi informasi dan komunikasi
(TIK) atau yang disebut juga dengan Information and Communication Technology (ICT), bukan sesuatu yang dianggap baru lagi. Wijayanto (2017), dalam penelitiannya membuktikan bahwa penggunakan media pembelajaran anak berbasis teknologi mampu meningkatkan kreatifitas dan efektifitas dalam pembelajaran pada anak-anak usia dini. Kegiatan penelitian ini bertujuan untuk membantu meningkatkan keterampilan para siswa dalam menggunakan TIK sebagai salah satu media pembelajaran.

Penelitian ini mengambil subjek penelitian pada 15 orang siswa PAUD di PAUD Musafir, Manado, Sulawesi Utara. Sasaran pada kegiatan pengabdian di PAUD ini adalah kelompok anak besar, dengan kategori umur 4-6 tahun.

Pengembangan

aplikasi didasarkan pada pokok-pokok Program Pengembangan Kompetensi (PPK) yang diterapkan pada PAUD Musafir terutama pada aspek kognitif. Pokok-pokok Program Pengembangan tersebut yaitu, nilai agama dan moral, aspek fisik dan motorik, aspek kognitif, bahasa, aspek sosial emosional, dan seni.

\section{METODOLOGI PENELITIAN}

Metode pengembangan sistem yang digunakan dalam kegiatan ini adalah metodologi Multimedia Development Life Cycle (MDLC) (Binanto, 2010). MDLC terdiri dari enam tahap, yaitu penbentukan konsep (concept), perancangan (design), pengumpulan materi (material collecting), pengembangan (assembly), pengujian (testing), dan distribusi (distribution).

\section{Tahap Pembentukan Konsep}

Tahap pembentukan konsep adalah tahapan dimana langkah analisis kebutuhan awal sistem dilakukan. Tahapan ini mencakup analisis data awal, penyusunan konsep perancangan, dan persiapan untuk melakukan perancangan sistem. 
Tahap Pembentukan Konsep pada penelitian ini dimulai dari mengumpulkan data hasil pengujian sistem sebelumnya yang telah diimplementasi. Dari implementasi sistem sebelumnya, terdapat beberapa kekurangan sistem seperti bahasa yang digunakan dan masalah tampilan yang dirasa cukup kompleks untuk digunakan anak-anak usia dini. Dari hasil analisis tersebut maka dihasilkan konsep untuk membuat aplikasi permainan edukatif ini berbasis desktop, dirancangan menggunakan bahasa Indonesia, dan juga harus mampu menjawab permasalahan tampilan pada aplikasi sebelumnya. Sasaran pengguna aplikasi juga ditentukan pada tahapan ini.

\section{Tahap Perancangan}

Pada tahap perancangan dihasilkan rancangan sistem yang akan dikembangkan berdasarkan hasil analisis awal. Tahapan ini dimulai dari merancang menu-menu yang akan dihasilkan berdasarkan pada pokokpokok Program Pengembangan Kompetensi (PPK) yang diterapkan pada Instansi PAUD. Berdasarkan daftar PKK aspek kognitif, dibuat pemetaan dengan menu-menu yang kira-kira dapat terlibat dalam peningkatan kompetensi yang dimaksud.

Tahapan ini juga menentukan penamaan dan penempatan konten pda aplikasi ini. Termasuk pemilihan tema, dan gambaran "kasar" sistem secara keseluruhan. Aplikasi permainan edukatif ini dirancang berbasis desktop dengan pertimbangan kenyamanan aspek visual dari pengguna.

\section{Tahap Pengumpulan Materi}

Berdasarkan tahap perancangan, kemudian dikembangkan dan dicari material yang sesuai untuk ditempatkan pada aplikasi ini. Tahap ini disebut juga dengan tahap pengumpulan materi.

Pada tahap ini juga ditentukan aplikasi pengembangan apa yang akan digunakan dalam mengembangkan aplikasi permainan edukatif yang sesuai dengan kebutuhan.

Proses perancangan gambar yang akan digunakan sebagai latar aplikasi, gambar yang akan digunakan pada masing-masing menu, font dan audio yang cocok digunakan pada aplikasi juga ditentukan pada tahap ini.

\section{Tahap Pengembangan}

Perangkat pengembangan aplikasi permainan yang digunakan pada aplikasi ini adalah Construct 2.

\section{Tahap Pengujian}

Pada tahap pengujian aplikasi permainan edukatif langsung diujicoba pada pengguna sekunder aplikasi, dalam hal ini merupakan siswa dan tenaga pengajar PAUD.

Pengujian dilaksanakan pada 15 anak-anak PAUD berusia 3-5 Tahun dengan bimbingan para tenaga pendidik.

\section{Tahap Distribusi}

Tahap distribusi, aplikasi permainan edukatif sudah dieksport ke dalam bentuk/ekstensi yang sesuai dan sudah siap untuk didistribusikan ke pengguna.

\section{HASIL PENELITIAN DAN PEMBAHASAN}

Aplikasi yang dikembangkan berupa aplikasi permainan edukatif berbasis desktop. Aplikasi ini dapat diinstal pada system operasi berbasis Microsoft Windows maupun system operasi lainnya yang bisa mengeksekusi file dengan ekstensi .exe.

Masing-masing menu memiliki tiga pilhan sub-menu yang dapat dimainkan.

Berikut merupakan peta konten permainan edukatif yang dapat dimainkan pada aplikasi ini. 


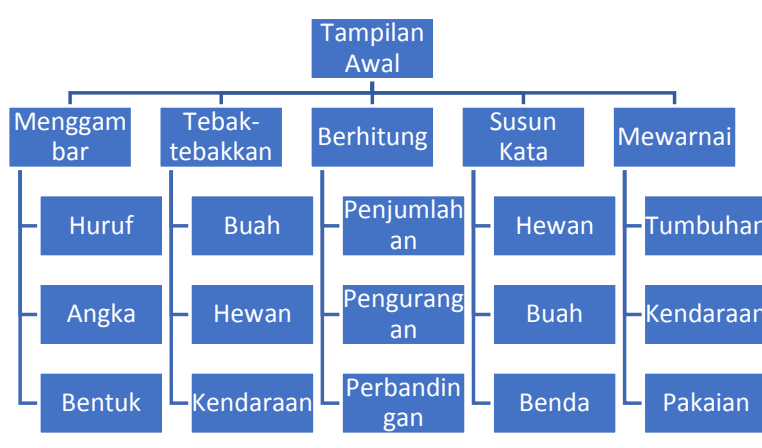

Gambar 1. Peta Menu Permainan Edukatif

Gambar 2 merupakan tampilan untuk masuk ke dalam halaman menu aplikasi. Cara untuk masuk kehalaman menu game yaitu dengan cara menekan tombol play yang pada halaman utama ini.

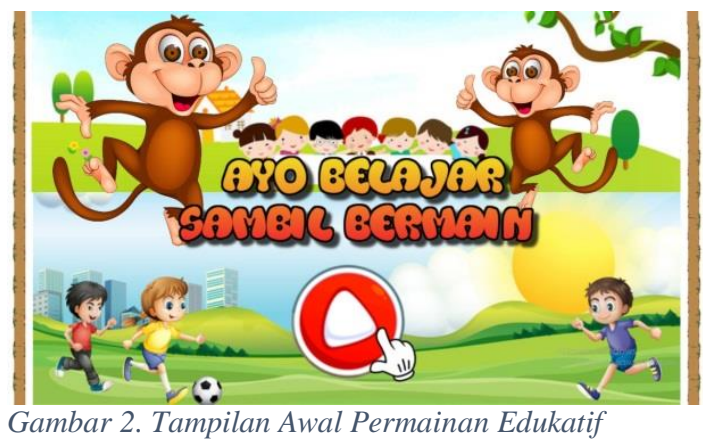

Jenis-jenis permainan yang dapat dimainkan pada aplikasi ini dapat dilihat pada Gambar 3. Terdapat 5 (lima) fitur yang terdapat di dalam aplikasi ini antara lain, 1. Tebak-tebakkan, 2. Berhitung, 3. Menggambar 4. Susun kata, dan 5. Mewarnai. Untuk setiap menu utama terdapat 3 (tiga) sub-menu yang dapat diakses seperti yang terdapat pada Gambar 3, 4, dan 5.

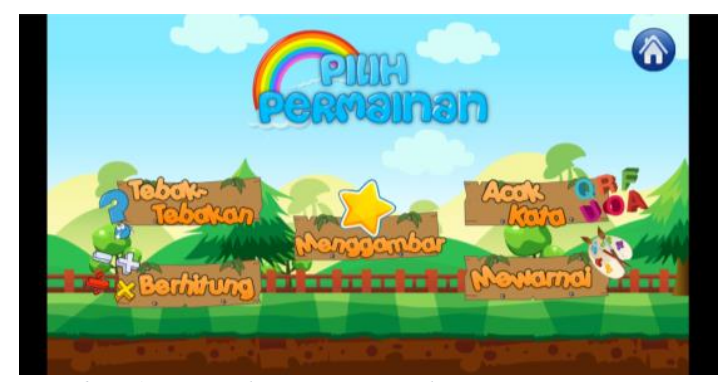

Gambar 3. Tampilan Menu Awal

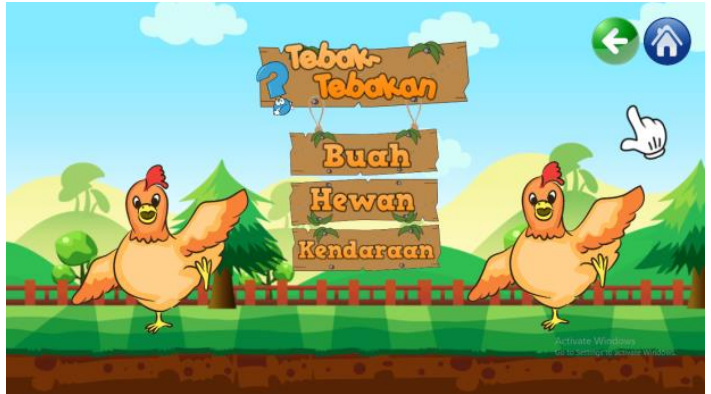

Gambar 4. Tampilan Pilihan Menu Tebak-tebakkan
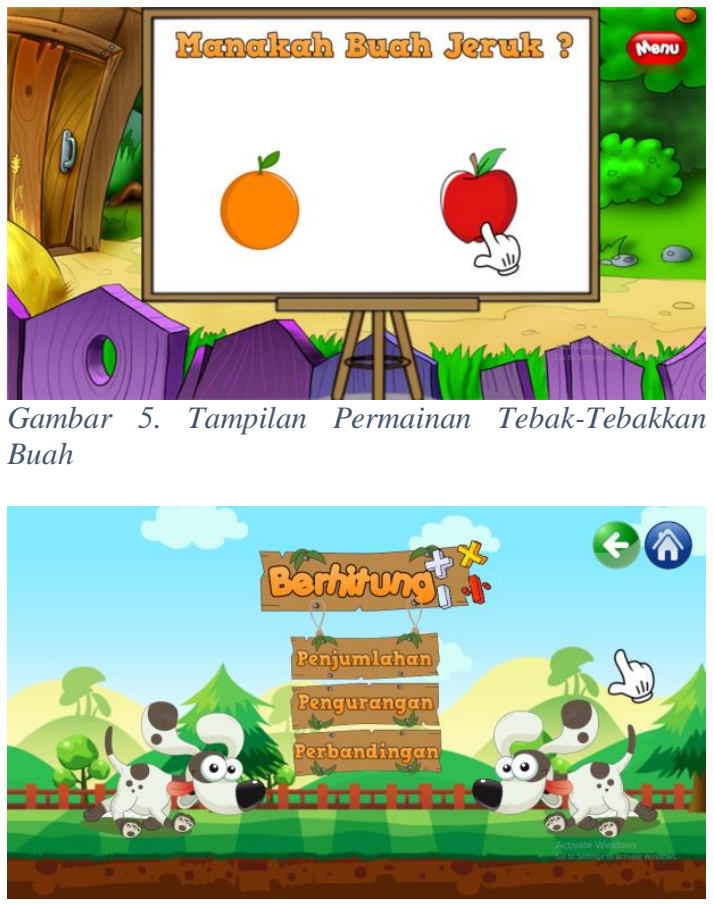

Dari hasil observasi singkat pada tahap awal pelaksanaan menunjukkan antusiasme anak-anak didik dalam memainkan aplikasi permainan edukatif ini. Sekitar 30\% anak dari jumlah peserta (15 orang anak) bahkan secara mandiri mampu memainkan permainan ini. Sedangkan sisanya membutuhkan bimbingan langsung pada beberapa menit pertama, tapi setelah sekitar 10 menit sudah menunjukkan kemandirian dalam memainkan aplikasi ini.

Karena terbatasnya jumlah content permainan pada sub-menu, anakanak menjadi cenderung cepat bosan ketika mengeksekusi satu menu dan ingin segera mengeksekusi menu selanjutnya. Diharapkan pada penelitian selanjutnya akan ditambahkan beberapa fitur pada sub-menu permainan yang ada, agar 
pengguna bisa memiliki lebih banyak pilihan fitur untuk dimainkan pada aplikasi ini.

\section{KESIMPULAN}

Penelitian ini menghasilkan aplikasi permainan edukatif yang terdiri dari 5 fitur yang terdapat di dalam aplikasi ini antara lain, 1. Tebak-tebakkan, 2. Berhitung, 3. Menggambar 4. Susun kata, dan 5. Mewarnai. Untuk setiap menu utama terdapat 3 (tiga) sub-menu yang dapat diakses. Aplikasi ini dikembangkan terutama untuk memicu perkembangan kognitif anak-anak PAUD.

Pengembangan dari aplikasi ini masih sangat dianjurkan, seperti penambahan fitur pen-skor-an, dan menambah jumlah permainan pada setiap sub-menu. Karena terbatasnya jumlah content permainan pada sub-menu, anakanak menjadi cendeung cepat bosan ketika mengeksekusi satu menu dan ingin segera mengeksekusi menu selanjutnya.

Untuk memahami efektifitas implementasi aplikasi permainan edukatif ini disarankan untuk melaksanakan penelitian dengan jangka waktu implementasi yang lebih lama. Jangka waktu implementasi penelitian ini hanya dilaksanakan dua pertemuan.

\section{DAFTAR PUSTAKA}

Binanto, I-. 2010. Multimedia Digital Dasar teori dan Pengembangannya. Yogyakarta: Andi.

Darsono, M., et al. (2000). Belajar dan Pembelajaran. Semarang: IKIP Semarang Press.

Ernawati. (2009). Pengelolaan Paud Terintegrasi Posyandu di Pos PAUD Tunas Bangsa. http://pengelolaanpaudterintegrasi-posyandu.html (diakses 17 Juli 2019).

Hainstock, E. G. (1999). Metode Pengajaran Montessori untuk Anak Prasekolah. Jakarta: Pustaka Delapratasa.
Sudono, A. (2000). Sumber Belajar dan

Alat Permainan. Jakarta: Grasindo.

Wijayanto, P. W., \& Siradj, Y. (2017). The Educational Game "Indoensian Tribes" for the Kindergarten Students. International Journal of Pendagogy and Teacher Education (IJPTE), Vol. 1 Issue 1, April 2017. 